\title{
連結石礫の流体力評価に関する研究 EVALUATION OF HYDRODYNAMIC FORCE ON TIED GRAVELS
}

\author{
前野詩朗 $^{1} \cdot$ 藤原実咲 ${ }^{2} \cdot$ 富田晃生 ${ }^{3} \cdot$ 山村 明 $^{4}$ ・忰熊公子 ${ }^{5}$ \\ Shiro MAENO, Misaki FUJIWARA, Akio TOMITA, Akira YAMAMURA and Kimiko KASEGUMA

\begin{abstract}
${ }^{1}$ 正会員 工博 岡山大学助教授 環境学研究科社会基盤環境学専攻（三700-8530 岡山市津島中 3-1-1）
2 学生会員 岡山大学環境学研究科社会基盤環境学専攻博士前期課程（干700-8530 岡山市津島中 3-1-1）

3 岡山大学環境理工学部環境デザイン工学科（†700-8530 岡山市津島中 3-1-1）
\end{abstract} \\ ${ }^{4}$ 日建工学株式会社 総合技術研究所（†160-0023 新宿区西新宿 6-10-1 日土地西新宿ビル 17F ) \\ 5 正会員 日建工学株式会社 総合技術研究所（†160-0023 新宿区西新宿 6-10-1 日土地西新宿ビル 17F)
}

\begin{abstract}
Nature friendly hydraulic structures made of natural stones such as ripraps have attracted attention in recent years. However, those structures are subject to failure problem under flood flow. Therefore, the authors proposed tied gravels to increase its stability against flood flow. Coefficients such as the drag and lift force are necessary in designing those structures. However, the authorized values for those coefficients are not established yet, the coefficients used for concrete structures are therefore applied in designing structures made of stones at present condition. This study aims to clarify the drag and lift coefficient for gravels and tied gravels experimentally.
\end{abstract}

Key Words : nature friendly structure, natural stone, tied gravel, drag coefficient, lift coefficient

\section{1.はじめに}

平成 9 年の河川法の改正にともない，環境に配慮 した「多自然型川づくり」が全国各地で進められる ようになった。しかし，その多くがコンクリート製 の従来型の護岸ブロックを多自然型に改良したもの であり, 今後進められる「多自然川づくり」では, さらに自然に優しい材料である自然石礫で構築され る水理構造物が望まれる。しかし, 石碟で構築され る構造物は, 前野ら ${ }^{1)}$, 2),3) が指摘しているように, 環 境機能には優れているものの, 洪水時の破壊に対す る強度不足が䀣念される。

そこで, 著者らは, 環境機能を保持したまま河床 保護機能を高めるために, 写真-1 に示すような自然 石を連結する工法を提案している。しかし, コンク リート製の護岸ブロックとは異なって, 形状や重量 がそれぞれ異なる自然石によって形成された連結石 礫に対する流体力評価に関する研究例は少なく, 作 用流体力を算定する際に必要となる抗力係数などは 類似のコンクリートブロックに適用されているもの

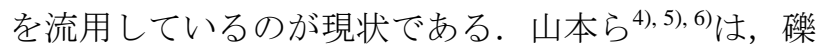
を 2 個連結したもの, あるいは 2 個連結したものを ワイヤで連結し，チェーンによりフレキシブルに繋 げた連結碩工（連結された碩と碟は離れている）の 安定性を検討し, 連結碩工の有効性などを明らかに しているが, 本研究で対象とする連結石磎はそれと
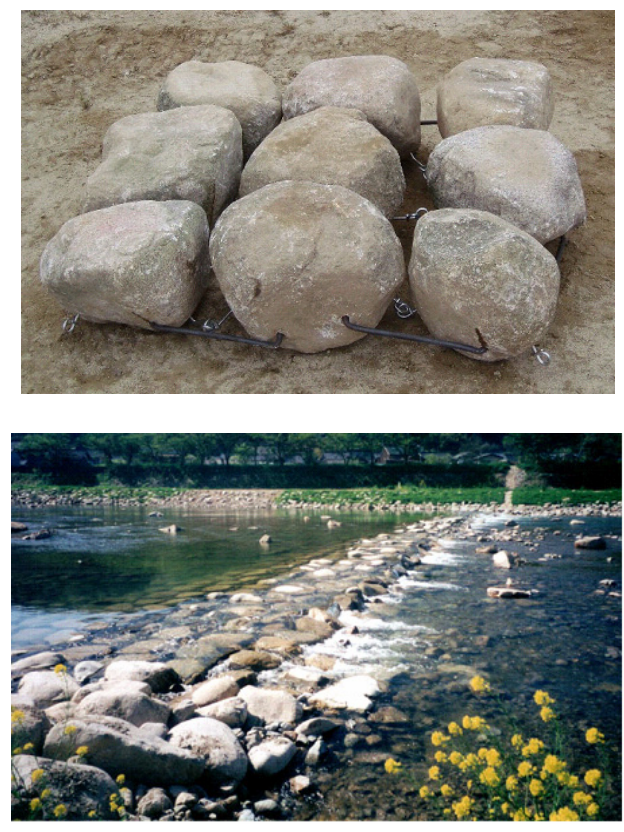

写真-1 連結石磎とその施工例

は構造が異なる. すなわち, 本研究で提案する連結 石礫は写真-2 に示すように, 比較的剛な形で連結さ れている点が特徵であり, 現時点では, 作用流体力 を算定する際に必要となる抗力係数などについて, 確立された設計基準がないのが現状である．護岸ブ ロックの試験法では, 単体, 群体上流端, 群体試験 
A

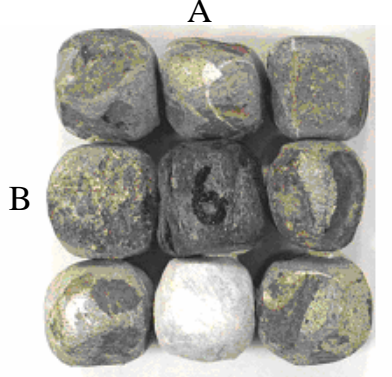

(a) 透過型

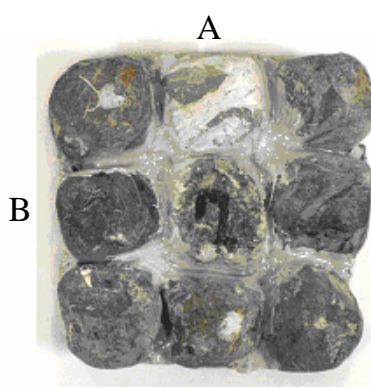

(b) 不透過型

写真-2 連結石碟模型

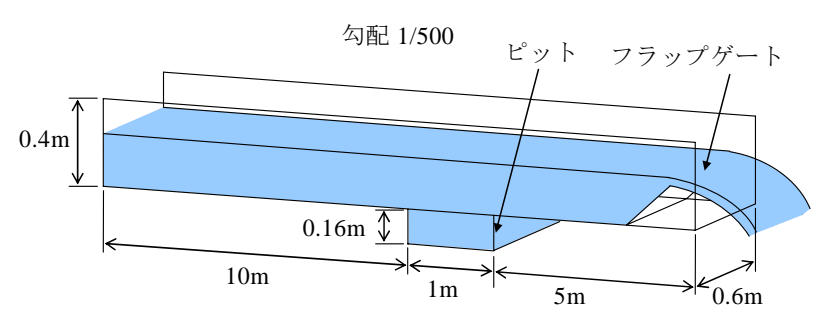

図-1 実験水路

の実施が規定されている. 本研究は, 基礎的研究として, 単体の連結石碩に作用寸る抗力・揚力係数を実験的に明 らかにし, めくれ, 滑動, 抜け出し破壊に関寸る連結石 碟の効果について検討するものである.

\section{2. 実験の概要}

実験に用いた水路は図-1 に示すような長さ $16 \mathrm{~m}$ ，幅 $0.6 \mathrm{~m}$, 勾配 $1 / 500$ の循環水路であり, 水路上流端より $10 \mathrm{~m}$ の位置に長さ $1 \mathrm{~m}$, 幅 $0.6 \mathrm{~m}$, 深さ $0.16 \mathrm{~m}$ のピットがある. また，水路下流端には水深を調節できるフラップゲート が設けられている.

計測機器は四分力計 (東京計測) を用い, 図-2 に示寸 ように水路ピット内に設置した．また，石碩は単体一個 または連結一群のみを河床に設置した. 分力計並びに石 礫の設置方法は護岸ブロックの試験法》に準じた.ここで $M_{c}$ はモーメントセンターを示寸. また, 四分力計の仕 様は表-1に示寸とおりである.

実験ケースを表-2 に示す．なお，今回は石碩の大きさ の違いによる流体力の変化を見るために三種類の大きさ の異なる石碩を用い，わかりやすく区別するため S:small, M:medium, L:lage と表示する. また, 連結によ る流体力の違いを見るために連結数の異なる石㗂を用 い, 石碩間に間隙があり透過性を有する場合(写真-2 (a)) を P: permeable，石礫間に間隙がなく不透過な場合(写真 -2(b))を IP: impermeable と表示し, 連結石碩については, 写真-2 に示寸 A, B 方向を上流側に向けることにより 2 方向を対象とした. さらに, $x$ : 縦断方向, $y$ : 横断方向, $z:$ 鉛直方向として石碟の規格も示す.

本実験では, 護岸ブロックの試験法》に準じて $1 \times 10^{4}$ か ら $4 \times 10^{4}$ 程度のレイノルズ数 $R_{e}$ が得られる流量 50,55 ,

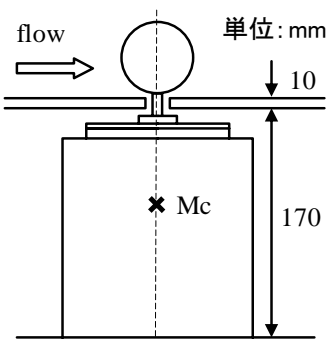

図-2 四分力計
表-1 四分力計の仕様

\begin{tabular}{|c|c|c|}
\hline 型式 & \multicolumn{2}{|c|}{$\begin{array}{c}\text { 防水型四分力計 } \\
\text { (Y116M2) }\end{array}$} \\
\hline \hline & 定格容量 & 定格出力 \\
\hline Fx方向 & $20 \mathrm{~N}$ & 約 $0.5 \mathrm{mV} / \mathrm{V}$ \\
\hline Fy方向 & $20 \mathrm{~N}$ & 約 $0.5 \mathrm{mV} / \mathrm{v}$ \\
\hline Fz方向 & $20 \mathrm{~N}$ & 約 $0.5 \mathrm{mV} / \mathrm{V}$ \\
\hline Mx方向 & $4 \mathrm{~N} \cdot \mathrm{m}$ & 約 $0.5 \mathrm{mV} / \mathrm{v}$ \\
\hline
\end{tabular}

表-2 実験ケース

\begin{tabular}{|c|c|c|c|}
\hline Case & 構成 & 規格 $(\mathrm{x} \cdot \mathrm{y} \cdot \mathrm{z})(\mathrm{cm})$ & 重量 $(\mathrm{N})$ \\
\hline \hline $1-1-\mathrm{S}$ & 1個 & $2.8 \cdot 2.8 \cdot 2.8$ & 0.38 \\
\hline $1-2-\mathrm{S}$ & 1個 & $2.9 \cdot 2.8 \cdot 2.5$ & 0.35 \\
\hline $1-3-\mathrm{S}$ & 1個 & $3.0 \cdot 2.8 \cdot 2.9$ & 0.38 \\
\hline $1-1-\mathrm{M}$ & 1 1個 & $5.3 \cdot 6.3 \cdot 4.4$ & 1.68 \\
\hline $1-2-\mathrm{M}$ & 1個 & $4.8 \cdot 5.7 \cdot 4.4$ & 1.54 \\
\hline $1-3-\mathrm{M}$ & 1 個 & $4.1 \cdot 5.6 \cdot 4.5$ & 1.57 \\
\hline $1-1-\mathrm{L}$ & 1 個 & $7.4 \cdot 8.3 \cdot 6.1$ & 4.77 \\
\hline $1-2-\mathrm{L}$ & 1 個 & $7.7 \cdot 9.8 \cdot 5.2$ & 5.07 \\
\hline $1-3-\mathrm{L}$ & 1個 & $7.4 \cdot 8.9 \cdot 5.6$ & 4.68 \\
\hline $4-\mathrm{P}-\mathrm{A}-\mathrm{S}$ & 4 個連結 & $5.8 \cdot 6.3 \cdot 2.9$ & 1.45 \\
\hline $4-\mathrm{P}-\mathrm{B}-\mathrm{S}$ & 4個連結 & $6.3 \cdot 5.8 \cdot 2.9$ & 1.45 \\
\hline $4-\mathrm{IP}-\mathrm{A}-\mathrm{S}$ & 4個連結 & $6.2 \cdot 6.5 \cdot 2.9$ & 1.59 \\
\hline $4-\mathrm{IP}-\mathrm{B}-\mathrm{S}$ & 4 個連結 & $6.5 \cdot 6.2 \cdot 2.9$ & 1.59 \\
\hline $9-\mathrm{P}-\mathrm{A}-\mathrm{S}$ & 9個連結 & $8.9 \cdot 8.7 \cdot 3.0$ & 3.09 \\
\hline $9-\mathrm{P}-\mathrm{B}-\mathrm{S}$ & 9個連結 & $8.7 \cdot 8.9 \cdot 3.0$ & 3.09 \\
\hline $9-\mathrm{IP}-\mathrm{A}-\mathrm{S}$ & 9個連結 & $8.9 \cdot 9.0 \cdot 3.0$ & 3.16 \\
\hline $9-\mathrm{IP}-\mathrm{B}-\mathrm{S}$ & 9 個連結 & $9.0 \cdot 8.9 \cdot 3.0$ & 3.16 \\
\hline $9-\mathrm{P}-\mathrm{A}-\mathrm{M}$ & 9個連結 & $13.4 \cdot 14.0 \cdot 4.6$ & 7.71 \\
\hline $9-\mathrm{P}-\mathrm{B}-\mathrm{M}$ & 9個連結 & $14.0 \cdot 13.4 \cdot 4.6$ & 7.71 \\
\hline $9-\mathrm{IP}-\mathrm{A}-\mathrm{M}$ & 9個連結 & $13.4 \cdot 14.0 \cdot 4.6$ & 8.54 \\
\hline $9-\mathrm{IP}-\mathrm{B}-\mathrm{M}$ & 9個連結 & $14.0 \cdot 13.4 \cdot 4.6$ & 8.54 \\
\hline
\end{tabular}

60，65, 70e/s を与えた. この時のフルード数 $F_{r}$ は 0.34 から 0.68 である. 各流量について水深 $h$, 流下方向の近 傍流速 $V_{d}$, 石碩に働く流体力である抗力 $D$, 揚力 $L$, モーメント $M$ を計測した. なお, 横断方向の作用力は小 さいため本研究では検討していない.

\section{3. 実験結果および考察}

本試験では，水路について実河道における流れの状態 を再現するため, 水路上流区間で河床粗度による境界層 が十分に発達するよう, 計測地点から上流側に $2.4 \mathrm{~m}$, 下 流側に $1.8 \mathrm{~m}$ の区間に人工芝を敷設した．図-3 は，計測 地点から $30 \mathrm{~cm}$ 間隔に上流側 8 ポイント, 下流側 5 ポイ ントにおいてポイントゲージにより水面形を求めた結果 である.これにより計測地点付近では十分に流れが安定 していることが確認された.

次に, 護岸ブロックの試験法》に準じて, 一様な流れが 形成できているかの確認を行う。石碟のない状態で計測 地点より上流側 $5 \mathrm{~cm}$ の地点の実測流速分布と次式(1) に示寸粗面対数則との比較を図-4に示寸. 


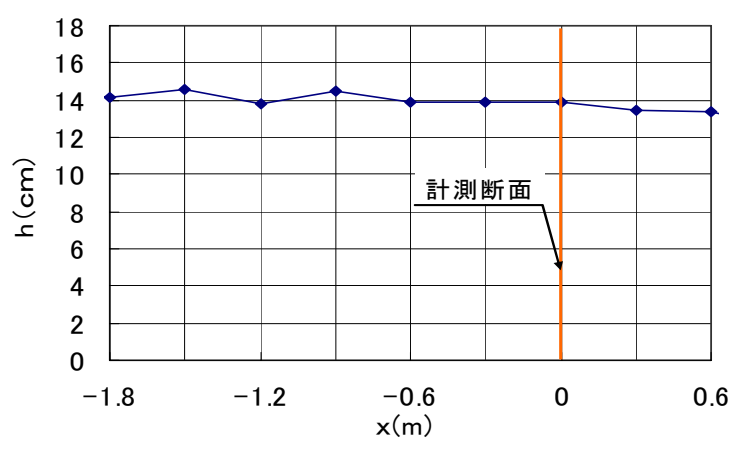

図-3 水面形
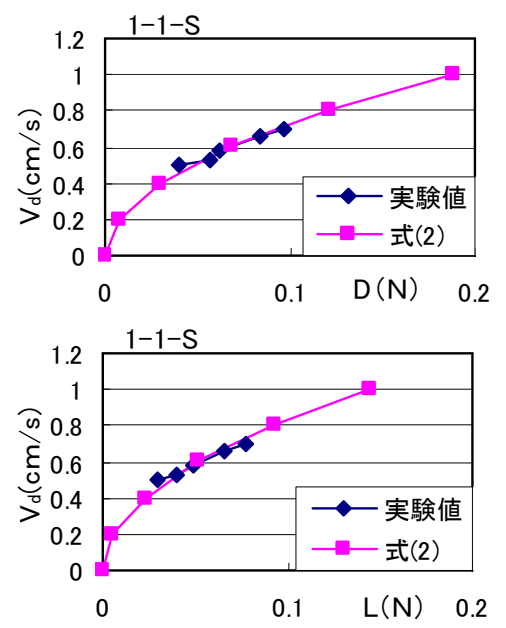

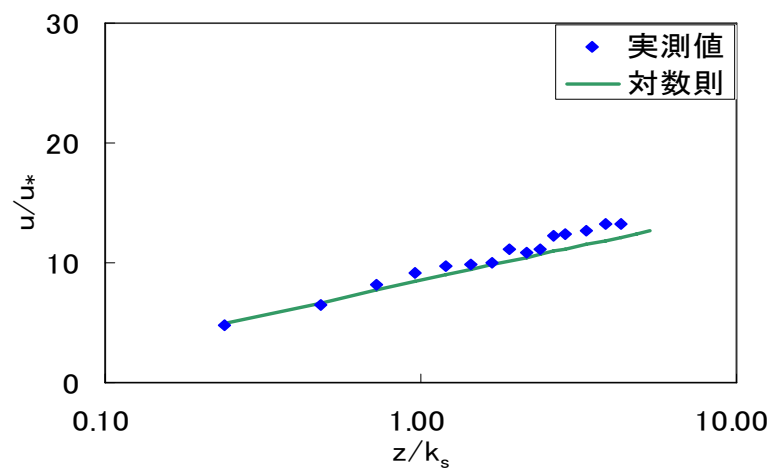

図-4 流速分布と対数則との比較
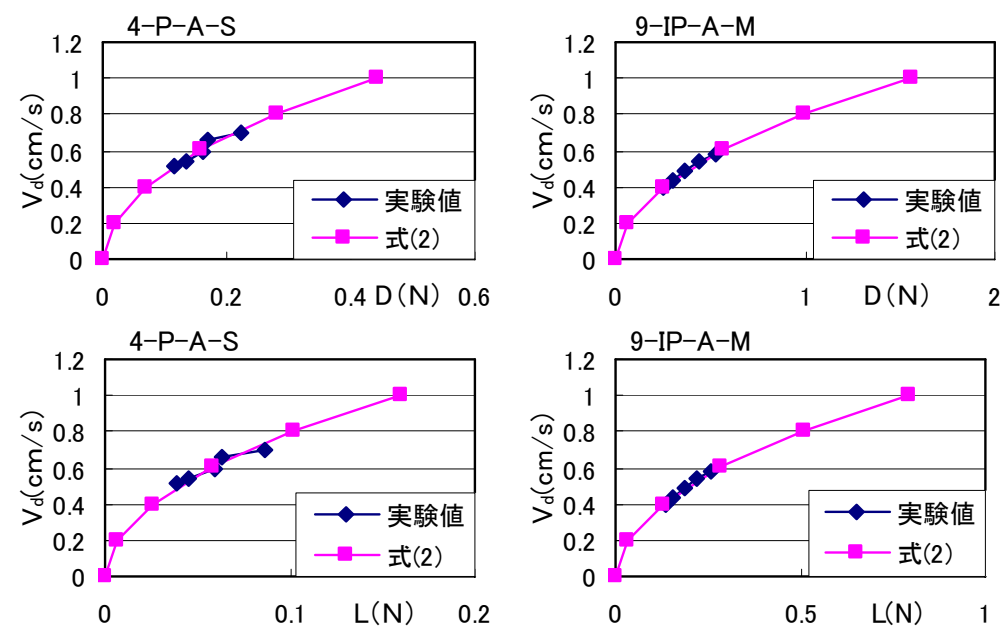

図-5 実験值と式(2)との比較

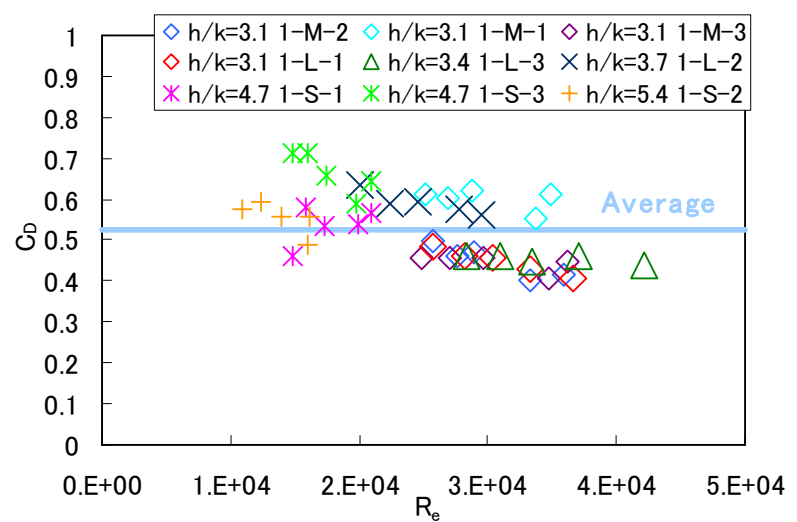

図-6 $C_{D}$ と $R_{e} \cdot h / k$ との関係

$$
\frac{u}{u_{*}}=5.75 \log _{10} \frac{z}{k_{s}}+8.5
$$

ここに, $u$ : 流速, $u_{*}$ : 摩擦速度, $z$ : 河床からの距離, $k_{s}$ : 粗度高さである.

図より， $u / u_{*}$ は式(1)で示守粗面対数則に概ね従って いることがわかる．また， $x=0 \mathrm{~cm},-30 \mathrm{~cm},-60 \mathrm{~cm}$, の地 点における流速分布と水深がほぼ一致していたことか ら，計測地点において，境界層の発達したほぼ一様な流 れが形成されていることを確認した.

次に, 次式(2)に示す抗力・揚力を算出する際に必要と なる抗力係数 $C_{D}$ と揚力係数 $C_{L}$ について検討する.

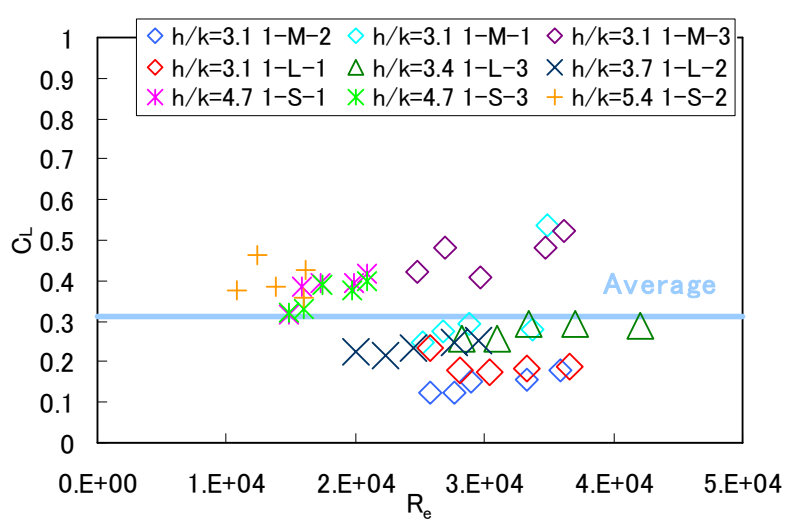

図-7 $C_{L}$ と $R_{e} \cdot h / k$ との関係

$$
D=\frac{1}{2} \rho C_{D} A_{D} V_{d}^{2}, L=\frac{1}{2} \rho C_{L} A_{L} V_{d}^{2}
$$

ここに, $A_{D}, A_{L}$ : 抗力, 揚力作用面積, $V_{d}$ : 近傍流速, $\rho$ : 水の密度である. ここでの近傍流速 $V_{d}$ は護岸ブロ ックの試験法 ${ }^{7)}$ に準じてブロック全体高 $k$ における流速 とし, $x=-30 \mathrm{~cm}$ の水路中央地点で計測した.

図-5 は，実験結果より得られる $C_{D}, C_{L}$ の平均值に より算出される $D, L$ と本実験結果を比較したものであ る. 図には，試験体 1 個・4 個連結・9 個連結について代 表的なものを示している. 図より，抗力，揚力が速度の 2 乗に比例し, 抗力・揚力係数として一定值を用いてよ いことがわかる。 


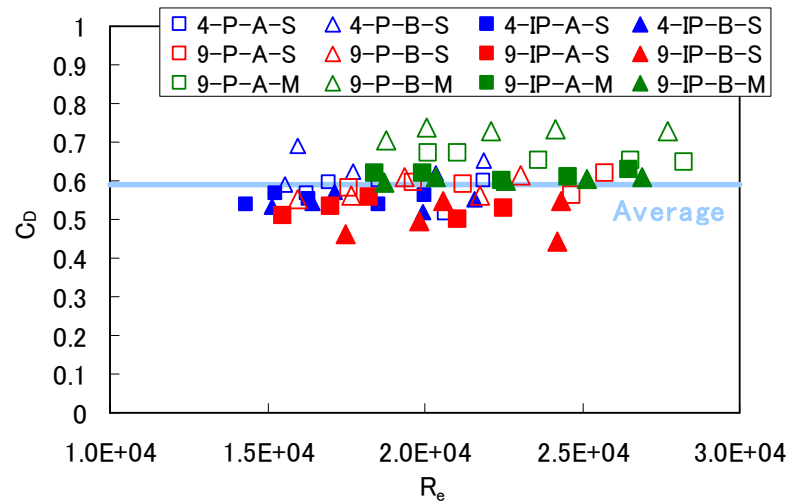

図-8 $\quad C_{D}$ と $R_{e}$ との関係

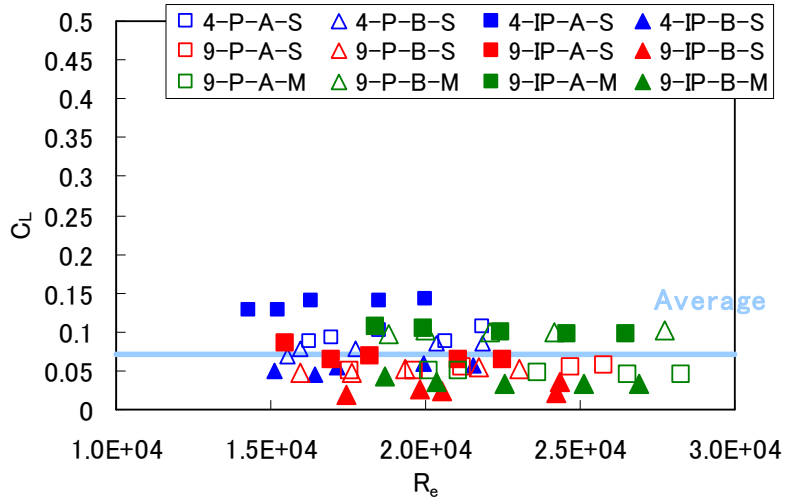

図-9 $C_{L}$ と $R_{e}$ との関係
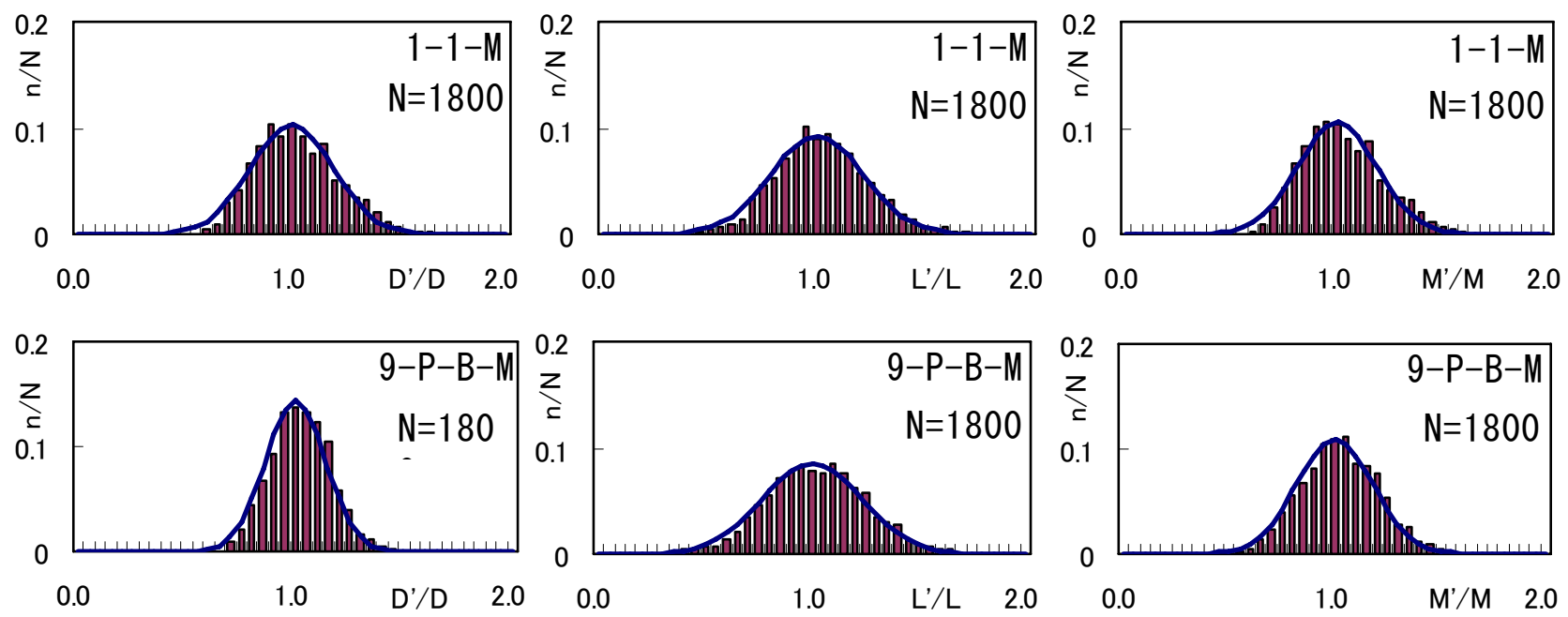

図-10 ヒストグラムと確率密度関数

\section{（1）抗力・揚力係数の結果と考察}

図-6 および図-7 は, 1 個の非連結石砂についてそれぞ れ, $C_{D}, C_{L}$ とレイノルズ数 $R_{e}$ の関係について, 相対水 深 $h / k$ をパラメータとして示したものである. なお，図 では粒径の違いを記号の大きさで示している．図-6の $C_{D}$ 值と相対水深 $h / k$ の関係からは, 相対水深が小さく なるにつれて $C_{D}$ も小さくなる傾向が見られる. 重枝ら ${ }^{8)}$ が示したように，相対水深が小さくなるにつれ $C_{D}$ は大 きくなることが予想されるが，本実験の場合，有意な傾 向は見られなかった．これは，石砶形状や大きさがケー スごとに異なることなどが原因であると考えられる．粒 径についても同様に有意な変化傾向は認められない.ま た，図-7 より， $C_{L}$ は $C_{D}$ よりもばらつきが大きくなる ことがわかる．しかし， $C_{L}$ についても今回の実験の範 囲では，相対水深や粒径の変化による有意な変化傾向は 認められなかった，次節では， $C_{D}, C_{L}$ として図中の実 線で示すそれぞれの平均值 $C_{D}=0.53, C_{L}=0.31$ を用い て，破壊抵抗に関する検討を行う。

次に，図-8および図-9 は，連結石㗂について，それぞ れ, $C_{D}, C_{L}$ とレイノルズ数 $R_{e}$ の関係を示している. 不 透過型と透過型の石碟を記号の塗りつぶしの有無で表し ている.これらの図より， $C_{D}$ については，石礫数によ
る違いは確認できないが，透過型の方が不透過型よりも 若干大きくなる傾向が見られるものの，有意な差がある とは言えない，一方， $C_{L}$ については，石礫数の違い， 透過・不透過による違いが確認できなかった。 よって, 多少のばらつきはあるものの, ほぼ同程度であると考え， 次節では $C_{D}, C_{L}$ として図中の実線で示寸それぞれの平 均值 $C_{D}=0.59, C_{L}=0.07$ を用いて, 破壊抵抗に関する 検討を行う。なお，これらの係数值は類似した形状のコ ンクリートブロックを対象とした設計值 $C_{D}=0.6$, $C_{L}=0.1$ 程度と同オーダーであり, 妥当な值と判断でき る.

\section{（2）破壊に関する結果と考察}

連結石碩を実河川に敷設するに当たっては，護岸の力 学設計法9に示されるように石礫の(1)めくれ(2)滑動(3)抜 け出しに関して破壊の有無を検討しておく必要がある. ここでは，破壊駆動力と抵抗力の比による破壊指数を求 め，石砂を連結することによる安定性の向上について検 討する.

まず，(1)，(2)，(3)の現象は，時間平均された流体力で はなく，瞬間的な流体力による影響に依存するため，瞬 間的な流体力を把握することが必要となる．図-10 に代 
表的な例として，1-1-M と 9-P-B-M の D ，L，M につ いて，それぞれの瞬間流体力 $F^{\prime}$ を時間平均流体力 $F$ で 無次元化したヒストグラムの例を示した. 図中の実線は, 標準偏差 $F_{\sigma}$ を用いて式(3)で表される正規分布の確率密 度関数である。

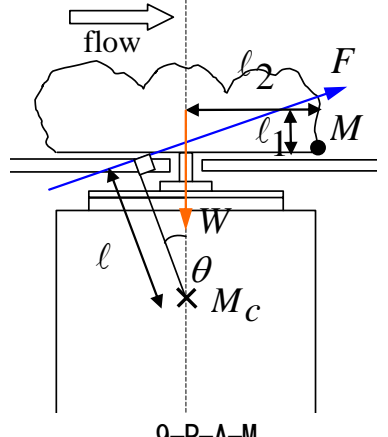

9-P-A-M

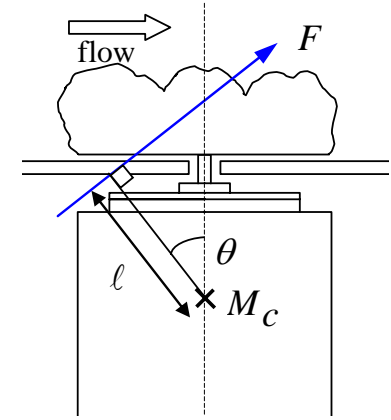

9-IP-A-M
図-11 作用線位置

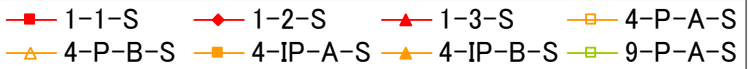

$\triangle 9-P-B-S-6-I P-A-S \backsim 9-I P-B-S$

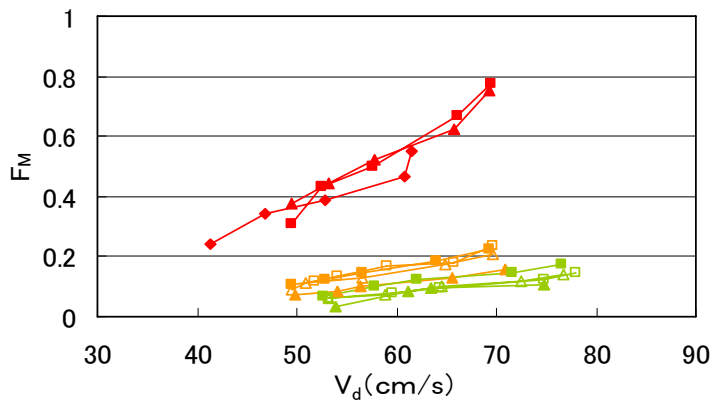

(a) めくれ

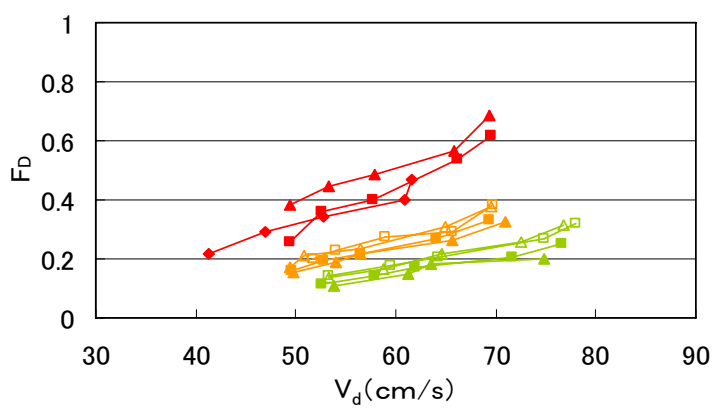

(b) 滑動

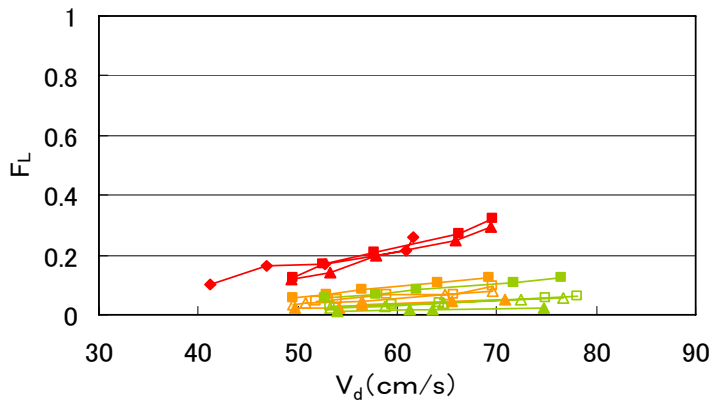

(c) 抜け出し

図-12 破壊指数

$$
f\left(\frac{F^{\prime}}{F}\right)=\frac{1}{\sqrt{2 \pi} F_{\sigma}} \exp \left(-\left(\frac{F^{\prime}-F}{F}\right)^{2} / 2 F_{\sigma}^{2}\right)
$$

図より，作用流体力の変動はほぼ正規分布に従ってい ることがわかる。このことは，実際の設計の際には，正 規分布を仮定して流体力の変動を推定できることを示し ている。.また，石礫には最大で平均流体力 $F$ の 1.5 倍程 度の瞬間流体力 $F^{\prime}$ が作用しいている. 本来であれば, 鬼 束ら ${ }^{10)}$ が指摘しているように，時間平均流体力 $F$ のみな らず標準偏差 $F_{\sigma}$, 安全率を用いて変動流体力を割り増 しして石礫の安定性を検討する必要がある。しかし，石 礫に対する安全率の設定等の基準が明確でないこと，ま た，今回は石硯の連結効果に焦点を当てて検討を行うこ となどを考慮して，以下では石碟に作用する流体力とし て時間平均流体力 $F$ を用いることとする.

次に，図-11 に示寸石磕に働く流体力の作用位置を決 定するため，以下に示す式(4)，(5)によって定義される

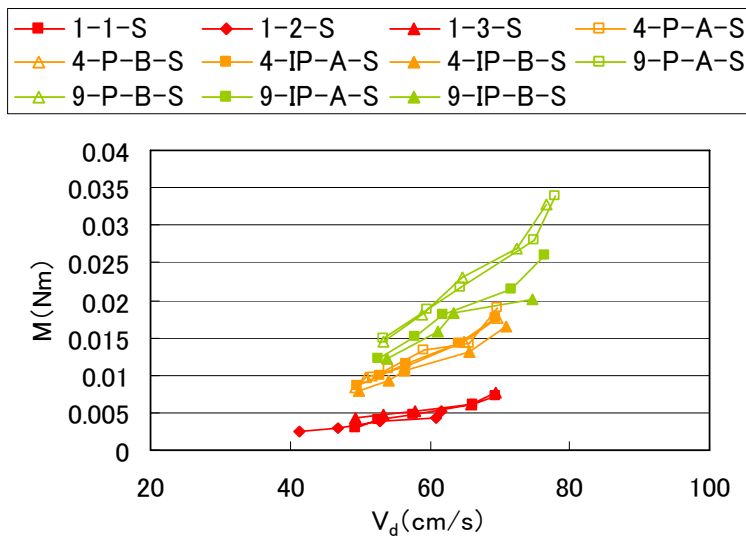

(a) 流速と $M$ の関係

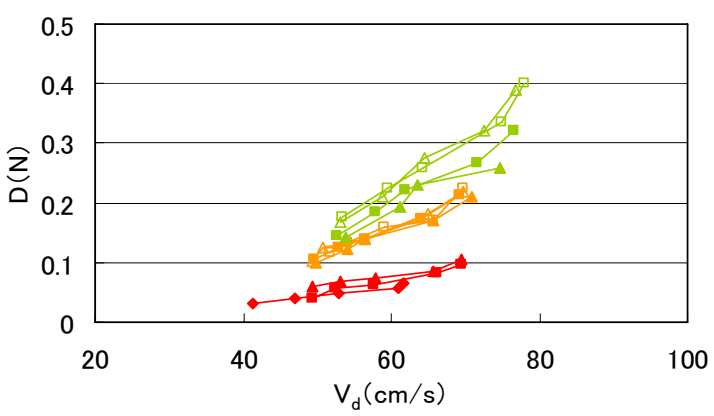

(b) 流速と $D$ の関係

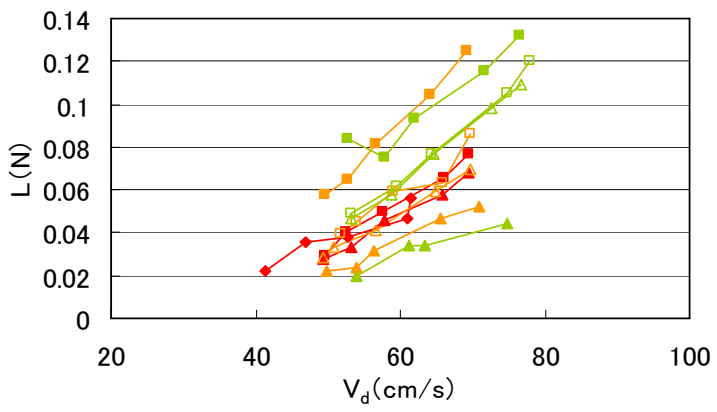

(c) 流速と $L$ の関係

図-13 流体力 
$M_{C}$ から作用線までの距離 $\ell$ と， $M_{C}$ から作用線へ下ろ した垂線の成寸角度 $\theta$ を算出した。

$$
\begin{aligned}
& \ell=M / \sqrt{D^{2}+L^{2}} \\
& \theta=\tan ^{-1}(L / D)
\end{aligned}
$$

その結果，石礫によって多少のばらつきはあることが わかった. 図-11 にその代表例を示寸. 図より，作用線 は石碩の重心付近あるいはやや下流寄りを通ることがわ かる.このことから以下では, 流体力は石礫の重心に働 くものとして検討する.

(1)のめくれについては，抗力と揚力によって生じる作 用流体力に対する図-11 左図中の $\mathrm{M}$ 点でのモーメント を, 水中重量 $W$ によって生じる $\mathrm{M}$ 点での抵抗モーメン トで除することによって破壊指数 $F_{M}$ を算出した. $F_{M}$ が 1 以上になるとめくれ破壊が生じる.

$$
F_{M}=\left(D \cdot \ell_{1}+L \cdot \ell_{2}\right) / W \cdot \ell_{2}
$$

これによって得られた結果を図-12 (a)に示寸.また, 各石 碩に働く流体力 $M$ の結果を図-13(a) に示寸. 図-13(a) から連結数が多くなるほど $M$ が大きくなることがわか る. 一方, 図-12(a)より, 破壊指数については石硆数が 多くなるほど減少する傾向があることが確認され，9 個 の連結石磼の破壊指数が最も小さくなり, 連結の効果が 確認できる.

(2)の滑動については，効力を，河床と石礫間に作用す る摩擦力で除すことによって滑りの破壊指数 $F_{D}$ を算出 した.

$$
F_{D}=D / \mu W
$$

ここで摩擦力を求める際に利用寸る静止摩擦係数 $\mu$ は, 河床の一般的な值である 0.65 とした. これによって得ら れた結果を図-12(b)に示寸. また，各石碩に働く流体力 $D$ の結果を図-13(b)に示寸. 図より, 連結数が多くなる ほど流体力 $D$ が大きくなるが，めくれの場合と同様に 9 個の石碩の破壊指数が最も小さくなり, 石礫数が多くな るほど破壊指数が減少することが確認された.

(3)の抜け出しについては，揚力を，自重で除寸ことに よって破壊指数 $F_{L}$ を求めた.

$$
F_{L}=L / W
$$

これによって得られた結果を図-12 (c) に示寸. また, 各 石硆に働く流体力 $L$ の結果を図-13(c)に示寸. 図より, 多少データにばらつきは見られるが，概ね連結数が多く なるほど流体力 $L$ が大きくなることがわかる. 抜け出し の場合も，9 個の石磎の破壊指数が最も小さく，石䃯数 が多くなるほど破壊指数は減少することが確認された.

以上より，連結数が多くなるほど，いずれの破壊モ一 ドに対しても安定性が増すことが確認された. また, 連 結なしの石碩の場合は，めくれによる破壊が滑動による 破壊の危険性よりも大きいが，石磥を連結すると逆に， 滑動による破壊の危険性の方が大きくなる. したがって, 連結石碩を設計する際には，できる限り抗力作用面積を 小さく寸ることが安定性の増加に繋がることがわかる.

なお, 写真-2 に示すように石㗂を 9 個連結した場合と,
重量が同じで，連結無しの場合，すなわち，一個の石碩 の9倍の重量を持つと仮定した石碑について, 本実験で 得られた抗力・揚力係数を用いて, めくれ, 滑動, 抜け 出しに関する破壊指数を試算した結果, それぞれ約 3 倍, 1.3 倍, 2.1 倍に増加し, 破壊に対寸る耐力は連結石碩の 方が大きくなることがわかった．このことからも，石磼 を連結する効果は大きいことが確認された.

\section{4. 結論}

本研究は，単体の連結石碩における抗力・揚力係数を 実験的に検討した．また，めくれ・滑動・抜け出しに対 寸る破壊抵抗について検討した. 以下に，得られた知見 について示す.

1) 単体石礫並びに連結石碟の抗力・揚力係数を明らかに した.

2) 連結数が多くなるほど, いずれの破壊モードに対して も安定性が増すことから，連結石礫が破壊に対して有効 であることが確認された。

3) 連結石砂については, 本実験条件下では, 滑動が最も 可能性の高い破壊であることが確認された.

本実験により，連結石碩の基本的な水理特性が明らか にされた. しかし，実際の設計に際しては，石硯周辺の 乱れ強度をどの程度見積もるかが重要である. 今後は, 堰直下流部や水制周辺, 跳水などによる乱れ強度の影響 もさらに検討する予定である。

\section{参考文献}

1) 前野詩朗, 道奥康治, 森永智, 大西利典 : 自然石を用いた 堰の水理特性, 水工学論文集, 第 46 巻, pp.493-498, 2002.

2) 前野詩朗, 道奥康治, 森永智, 大西利典 : 捨石堰の破壊機 構のモデル化, 水工学論文集, 第 47 巻, pp.781-786, 2003.

3) 前野詩朗, 道奥康治, 加瀬瑛斗, 菊池慶太 : 個別要素法を 用いた捨石堰の破壊予測, 水工学論文集, 第 49 巻, pp.787-792, 2005.

4) 山本太郎, 長谷川和義, 浅利修一 : 連結された 2 個の碩に 対する限界掃流力の評価について, 水工学論文集, 第 49 巻, pp.919-924, 2005.

5) 山本太郎, 長谷川和義, 浅利修一: 河床に設置された連結 礫工の安定性と破壊過程について, 水工学論文集, 第 50 巻, pp.955-960, 2006.

6) 山本太郎, 長谷川和義, 浅利修一 : 複数の礫が連結される ことによる流失限界の向上効果と掃流力評価について，土 木学会論文集, No.810/II-74, pp.31-42, 2006.

7) (財)土木研究センター:護岸ブロックの水理特性試験法マニ ユアル(第 2 版), 2003.

8) 重枝未玲, 秋山壽一郎，石原仁 : 常流あるいは射流中に置 かれた水没柱状物体に働く流体力，水工論文集，第 50 巻, pp.889-894, 2006.

9) 国土開発技術研究センター編: 護岸の力学設計法, 山海堂, 1999.

10) 鬼束幸樹, 秋山壽一郎, 重枝末玲, 中川達矢, 尾関弘明 : 斜水路下流部に配置された円筒形ブロックを用いた跳水制 御に関する実験的研究, 応用力学論文集 Vol.9, pp. 846-852, 2006.

(2006. 9. 30 受付) 